equal to $n$ decibels above the zero, its loudness level is declared to be $n$ phons. If, further, the reference tone has been regulated so that, as heard by an average ear under specified conditions, its loudness is assessed as equalling that of some other sound or noise, then the equivalent loudness of the latter is also declared to be $n$ phons.

In this way we overcome the difficulty that energy and loudness do not necessarily keep in step when the frequency is changed; and so, through the intermediary of a device akin to the standard candle of the photometrician, we can link the phon level with the decibel level, which latter is measurable by physical instruments called noise meters. Mr. Ll. S. Lloyd, feeling that all this is too difficult for a musician to comprehend, has based a simple explanation of it on the parallelism of the decibel to the musical interval of a major third (5/4) and has published it in an attractively written pamphlet. ("Decibels and Phons. A Musical Analogy. London" : Oxford University Press. 1s. 6d. net). The major third can naturally serve as an increment to build up a scale of pitch which is of course no less a logarithmic scale than any other musical scale, such as that of the more familiar octave. To interpret pitch as intensity apparently comes naturally to a race of selectively gifted 'monsters' whom the author amusingly creates for his purpose. Even those to whom the analogy may seem somewhat circuitous, will find the treatment pleasant reading, while there will, no doubt, be others, besides 'monsters' and musicians, to whom Mr. Lloyd's method of approach will commend itself.

\section{Science and the Welfare of Animals}

A ScIentric Investigations Committee has been formed by ULAWS (University of London Animal Welfare Society), which is in the course of being incorporated into the newly formed Universities Federation for Animal Welfare. The committee will concern itself with the acquisition of knowledge caJculated to benefit animals in their own interests as distinct from the interests of the human species. Its functions will be to define prolylems for inquiry, to advise as to the allocation of funds for the purpose, and to collect and communicate any new knowledge which may be of value for increasing the well-being or diminishing the sufferings of animals. A small grant has been made in aid of an ecological investigation relevant to the control of wild populations, which is frequently carried out by methods considered by many to be inhumane. Among the other topics in which the committee is interested are the widespread failure to utilize existing knowledge o dietetic principles; the problem of bait poisons the destruction of sea-birds by oil waste; and the use of an electrie goad as a substitute for the stick in droving cattle. The members of the committee are: Capt. C. W. Hume (chairman), Dr. S. Graham Brade-Birks (hon. secretary), Dr. Paul Haas, Mr. H. R. Hewer and Dr. W. R. Wooldridge. Men of science who are in sympathy with the objects of the committee are invited to communicate with Dr.
S. Graham Brade-Birks, South-Eastern Agricultural College, Wye, Kent.

\section{London Scientific Film Society}

THE proposed formation of a scientific film society, which would give shows of scientific documentary films to its members and their guests, was announced in NATURE of June 4. Such a society has now been formed, under the name of the London Scientific Film Society, and its inaugural meeting was held on October 14 at the Conway Hall. At the meeting Mr. L. V. Chilton explained how the formation of the Society was a direct result of the work of the Association of Scientific Workers on scientific films. One of the functions of the Association is the promotion of a proper understanding of science by the general public, and of what science can do for society; the Association is therefore interested in the teaching of science and in the proper treatment of science on the screen. Mr. Arthur Elton referred to the London Film Society, which was formed eleven years ago and has had a broadening influence on the rsthetic film. He said that if the London Scientific Film Society is to be successful, it must reveal to the public both the achievements of science and the potentialities of the seientific documentary film. Such a society can do much to raise the standard of scientific accuracy of the films shown in public cinemas, and also to increase the number of scientific films shown. The first show of the Society will be held at 2.30 p.m. on Sunday, November 13, at the Academy Cinema. Particulars of the Society and forms of application for membership can be obtained from the Secretary at 28 Hogarth Rodd, S.W.5.

\section{Faiths and World Fellowship}

THE World Congress of Faiths was founded several years ago by Sir Francis Younghusband to promote a spirit of fellowship among mankind through religion. The object of the organization is to awaken and develop a world-loyalty, while allowing full play for the diversity of men, nations and faiths. There have been three congresses, in London, Oxford and Cambridge respectively in 1936, 1937 and 1938 ; and the proceedings have been published in volumes obtainable from the Secretary, World Congress of Faiths, 36 Victoria Street, London, S.W.1. Owing to the tension in the international situation, the committee of the Congress has decided to postpone the holding of the next congress at the American University, Beirut, and arrangements are being made for the 1939 Congress to be held in Paris. A meeting will be held in the Kensington Town Hall at 8.30 p.m. on October 31, at which Lord Gorell will take the chair, and Hindu, Jewish, Muslim and Christian speakers will deliver addresses on "The Crisis : through Faiths to Fellowship".

\section{Air-Raid Precautions}

Two publications recently issued by the British Steelwork Association, Steel House, Tothill Street, London, S.W.1, are of permanent value, although happily the international crisis is over. The first of 